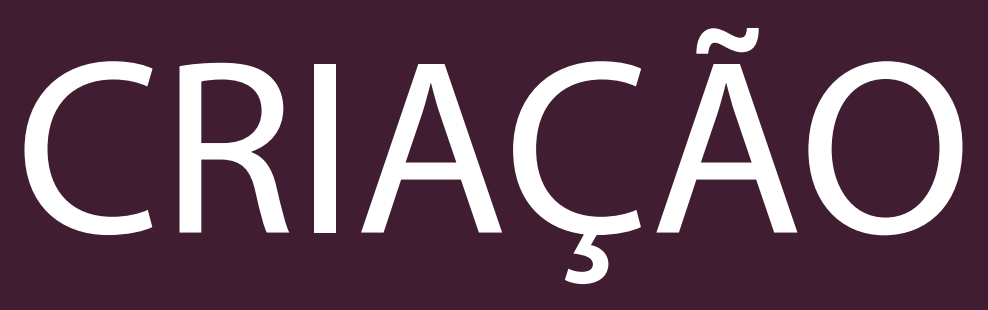





\title{
DO LIMBO AO NEON
}

\author{
- WELLINGTON AMANCIO SILVA
}

Quem poderá conter a vontade absurda de escrever?- questionou Elisabeth, num monólogo. Tem ela tudo em mãos. Tem a memória em mãos, tem o papel implacável, tão implacável de branco que retém o silêncio, e a caneta Bic indefectível, de bocal mordiscado. Tem o broquel e tem o escudo e tem a dúvida. Tem o broquel e tem o escudo e tem a dúvida. Tenta organizar seus pensamentos escrevendo e prossegue - "Ela aponta para mim e, como num espeIho estranho, me reconheço nela, mas não sou completamente dela. Embora não saiba onde pode haver elo, bifurcação ou distanciamento, não me importo, sigo-a como alguém que ao exílio vai. Se ela é mais forte do que eu e me transforma, em silêncio e segundo meus caprichos, também vou modificando-a, enxertando coisas que só eu sei e considero, ornamentando seus cabelos com alusões sem tempo e lugar, em camadas de frases simples e pessoais, que me satisfazem, e assim desconstruímos juntos os nossos votos, porque nestas frases ela comigo dialoga. Quando por um momento a esqueço, vejo-a refletida na pressa das pessoas, em seu desligamento do ambiente que as circunda. Eu olho para elas! Vejo ainda outras pessoas e outras, agora em silhuetas, por detrás do vidro escuro de uma loja e não reconheço nada de discreto nisso. Imagino seus interesses durarem até o momento em que estão ali, distraídas e desarmadas, depois perdem todo interesse, e por qualquer coisa. Sem jeito, apresso-me em desviar meu rosto, em direcionar meu foco de olhar para outro lugar e observo ainda outras pessoas que por não terem compromisso algum têm uma leveza no semblante - que denomino 'ausência de pensamentos' todavia no meio destas não encontro Marta. Nesse rito, me sinto culpada pela investida súbita de um pensamento que afirma que há coisas mais sérias do que as pessoas - e eu nem me acho egoísta. E aquela nuvem cinza, as pessoas, repleta de desejos aquosos, nem sabe que existo. Também no meio destas não encontro Marta. E as copas dos Ipês-Amarelos pendendo ao vento úmido, pendendo de um lado para outro, e dançando com aquela potência de quem tem um papel importante no teatro da vida, e, a um só tempo, como criança pequena, se põe a dançar ao primeiro som ritmado. No meio destas não encontro Marta. Se há coisas mais sérias do que as pessoas, lembro-me de pombos. Lembro-me que arrulham em cima dos telhados - e não há nesta vida algo mais sério! Volto ao meu mundo sem Marta e sinto-me impactada pelas coisas enfadonhas que me cercam: noto os transeuntes como escravos de um rei antigo 
e absoluto, de um Cronos em seu monte Pélion - e aí ela nunca estaria. Estes, em passos largos e sincrônicos, num badalar repetitivo de braços e tiques nervosos sutis, desaparecem através da névoa da memória. Eu, sem nada a fazer, me detenho em algum bar olhando impressionada e de longe a coisa mais bizarra do mundo que é a normalidade, o nomos. E enquanto passam me divirto criando histórias banais e inofensivas ao seu respeito, como fazíamos tradicionalmente, eu e Marta - eles sem saber, debruçados em seus afazeres, vão enriquecendo meu mundo de significado ficcional e eu escrevo. Quanto a mim, tenho trinta e dois anos de idade, e é só o que sei sobre mim, porque a matemática não falha. Estou afastada do emprego há oito meses, porque os 'especialistas' diagnosticaram-me portadora de algum distúrbio mental e assim o fizeram quando em nosso meio não encontrava Marta. Recomendaram-me não escrever mais (não imagino nada que possa estancar o ímpeto da escrita - a loucura seria uma espécie de inflamável, vai saber). Por isso mesmo, não me sobra outra opção senão escrever para que exista, de modo que eu possa entender essa existência; resta-me criar personagem para que frua uma vida social ao meu gosto e importa 'derramar algo de mim', como disse o poeta, sim, por sobre a folha branca, 'para que me liberte'. E eu sei que estas frases são já uns cliché desavergonhados e eu não me importo, mas o que não é cliché, por seu aspecto sedativo e curativo? São onze horas sem Marta e essa ausência se repete e se estampa nas paredes, nas lombadas dos livros, no lustre, no espelho, neste chá, na nódoa dos meus olhos, nessa janela que comprime as Braúnas e os Angicos, e em cada uma destas letras. Manhã nublada, garoa espaça. Há um burburinho que emana do fundo não sei de onde - talvez dos meus ouvidos. Saio à pracinha arborizadíssima a minha frente. Ali perto, uma senhora me olha momentaneamente, em meio à sua pressa de despachar dois ou três que se atentam às suas frutas. Tira de um dos bolsos do vestido umas moedas e algumas caem no chão, tilintando - todos olham. Antes de receberem o troco em moedas, aqueles se entreolham e vão-se com suas sacolas de plástico, todavia, no meio destas não encontro Marta. Por que escrevo tais detalhes? Epifanias. É o que me restou, e eu não me importo com o que me restou. Do outro lado, um esmoler menino me olha com candura e estende as mãos. Tenho algumas pequenas cédulas no bolso, mas dou-lhe apenas moedas, as de menor valor. Ele nem agradece dizendo 'Deus Ihe pague'. Fico pensando no sentido desta pequena frase: Deus Ihe pague... É quase uma metáfora da pobreza ou da riqueza (dependendo do ponto de vista). Uma justificação metafísica, como se dissesse para mim: 'moço, não tenho dinheiro e, se você me der algum, automaticamente não lhe deverei nada, pois alguém que tem há de lhe pagar um dia'. Um dia! Mas eu tenho pouco a falar sobre dinheiro, porque mesmo que se tenha em cofres, jamais se possui o dinheiro. Um mês trabalhado é o preço que se paga para que ficasse com dinheiro por um momento em nosso bolso. Um 
mês trabalhado é o preço da responsabilidade de carregá-lo até se esgotar, nas mãos dos nossos credores. Mas estas cifras todas se enchem de zeros à esquerda. Não me importo com o dinheiro; meus credores, sim. No bar, tomei o café e saí. Não havia muita coisa para se fazer numa cidade pequena e inútil. Eu também não oferecia qualquer serventia para aquela inútil cidade, porque também era inútil. Ora, minha inutilidade era escrever, e esse labor possibilitava-me sentir indefinidamente uma gama quase infinita de sensações e essa gama estendia-se do limbo ao neon - reforço! a contemplação me tornava inútil para aquela cidade, mas não para a minha própria. Por que escrever? Diz-se que há um tipo de devaneio muito característico (o único sentimento que contém na dor o gozo) inerente somente aos escritores - esses seres perturbados e egoístas, convencidos de que dizem algo importante, mas que suas perturbações não os tornam exclusivos - mas eu, sou um caso à parte, pois, eu mesmo sei que nunca soube escrever após um ponto-final. Rasgo meus papéis... apenas me exercito prazerosamente durante o percurso da escrita". No auge da produção literária de alguns, esta cresce até explodir, mas antes disso, e em uma espécie de esvaziamento estilístico, eles retinham-na até o último momento de um paroxismo que perdurava indefinidamente, até o instante antes do ponto-final, onde ela, às vezes não vale nem um vintém - disse em voz solene e continuou escrevendo - "Este devaneio pungente, de bico de pena, era uma peça caríssima de ourives, lapidada no âmago do ser e guardada como quem guarda uma pérola de grande valor. No entanto, verdadeiramente é ouro de tolo necessário para a sobrevivência de alguma ideia ou coisa, para algum fim que desconheço, pois tudo passa e passa logo: a folha amarelece, a tinta das letras esvaece, advêm as cãs, as dores de toda sorte que chegam para fazer passar a altivez, e ainda, depois de jazer seu autor o que resta é ausência sentida e é impossível expô-la, somente escrevê-la. Onde é que eu estava mesmo? Estava falando da cidade? Não. Não estava. Esqueçamos a cidade pequena com os seus personagens. Falemos da Literatura ainda não realizada, sobretudo da inutilidade do escrever. Como pessoa um tanto crítica, eu acho, posso dizer que a percepção da minha inutilidade de escrever é um sentimento antiguíssimo surgido no momento quando o homem pôs-se a fazer com as próprias mãos o seu fado - sim, todo fado é e se alimenta de mentiras, ou para ser mais eufemística, a ficção de todo fato tem gosto de vida, mas vida sem Marta. Esqueçamos por um momento toda essa baboseira. O motivo da minha queda foi Marta Perddi, mulher que hoje está distante de mim. Durante exatamente seis anos e três meses estivemos juntas. Construímos uma torre de sensações e impressões que depois ruiu. E foi assim: eu possuía tamanha potência em satisfazê-la naquilo que é passageiro, mas era incapaz de dar-lhe meu amor - escrevíamos. Desde muito, compreendemos que o amor, numa escala imaginária, estava muito abaixo das coisas que têm gosto intenso. Por isso, vai-se petrificando no 
panteão de coisas sem nexos, acumuladas de geração em geração. O Sabor quando encorpado não tem juízo de valor. Ora, podemos dizer que ele pode ser muito bom, ou muito ruim, nunca um meio-termo, e é assim que permanece, causando um abalo em nossa alcova - gostamos e não mais o esqueceremos (pensávamos eu e Marta). E não me importo mais se ela chorava e sofria; se estava ou não estava bem no trabalho; se há outro ombro amigo mais 'anatômico' é o que aqui não está. Só consigo me lembrar que, até onde fomos, ficamos viciados em nossas experiências afetivas desvirtuadas pelo Sabor e sobre isto conversávamos longamente, como se estivéssemos entre Platão e Sócrates. No começo ela quis me amar, porém como a maioria das mulheres já ama por natureza e em indefinidos modos de amar, para amar ela cedeu às tendências que meus instintos. E ela dizia: amor é sempre dado; sabor às vezes tem que ser tomado, mas ambos são irresistíveis. Até anoitei aqui. Ela dizia, penso que não provamos nosso amor com palavras, mesmo a demonstração do amor no dia a dia não é suficiente. Uma verdadeira prova de amor custa uma vida inteira. Não concordava muito com essas coisas, todavia me deixava ser o que quisesse dentro destas e até me transformava. Num bilhete para mim, Marta escreveu: amar é assumir conscientemente uma maneira de viver em que o outro é sempre uma grande novidade, todos os dias. Ea paz desse amor não entedia jamais. Nunca compreendi bem essas coisas, e acho que por causa disso ainda escrevo." I

WELLINGTON AMANCIO SILVA - É poeta, professor e revisor. Professor auxiliar na Universidade Federal de Alagoas - Campus Sertão; Mestre em Ecologia Humana e Gestão Socioambiental pela Universidade do Estado da Bahia - UNEB; Especialista em Ensino de Filosofia (UCAM). Publicou os livros Ontologia e Linguagem (filosofia da linguagem); Pensar a Indigência com Michel Foucault (filosofia); Eflúvio Maior (filosofia da arte); O Quasi-Haikai (versos); Epifania Amarela (versos); Ulisses e o Timoneiro (versos); Distímicos e Extrusivos (versos); Diálogos com Sebastos (teatro); O Catingueiro (romance) e O Reneval (versos). Site: facebook. com/caboclo.zeitgeist. Contato: wellington.silva@cedu.ufal.br 